SJ Quinney College of Law, University of Utah Utah Law Digital Commons

$8-2020$

\title{
Bystander Legislation: He Ain't Heavy, He's My Brother
}

Amos N. Guiora

Jessie E. Dyer

Follow this and additional works at: https://dc.law.utah.edu/scholarship

Part of the Criminal Law Commons, and the Law and Society Commons 


\title{
BYSTANDER LEGISLATION: HE AIN'T HEAVY, HE'S MY BROTHER $^{1}$
}

\author{
By: Amos N. Guiora* and Jessie E. Dyer **
}

\section{INTRODUCTION}

The words in the title of this article, from the Hollies iconic song, capture the essence and power of one individual providing assistance to another. It is the most basic of human interactions, reflecting the ability of one person and the need of the other. On the face of it, there is nothing particularly complicated or complex in such a notion. However, as history repeatedly teaches us and as we are reminded on a daily basis, we must not view this as a given. That assumption would be a profound mistake with grave consequences. It is for that reason, as we articulate in this article, that failure to provide minimal assistance to a person in peril must not go unpunished. The words below movingly capture what should be obvious to all.

The road is long, with many a winding turn

That lead us to (who knows) where, who knows where?

But I'm strong, strong enough to carry him

He ain't heavy - he's my brother

So on we go, his welfare is of my concern no burden is he to bear, we'll get there

For I know he would not encumber me He ain't heavy - he's my brother

\footnotetext{
* Professor of Law, S.J. Quinney College of Law, University of Utah.

** J.D. Candidate 2020, S.J. Quinney College of Law, University of Utah; Ms. Dyer co-wrote this article as part of her Quinney Fellowship. A portion of the research for this article was made possible through a Research Incentive Seed Grant, which was jointly funded by the University of Utah's Vice President for Research and the S.J. Quinney College of Law.

The authors would like to thank Scott Balderson, Anne-Marie-Cotton, Christine Hashimoto, Brian King, and John C. Lentz, Jr., for their invaluable insights.

${ }^{1}$ The reference is to the classic Hollies song, He Ain't Heavy, He's My Brother. See THE Hollies, He Ain'T HEAvy, He's My BROTHER (Abbey Road Studios 1969).
} 
If I'm laden at all, I'm laden with sadness

that everyone's heart isn't filled with the gladness

of love for one another.

It's a long, long road, from which there is no return

While we're on the way to there, why not share?

And the long doesn't weigh me down at all

He ain't heavy - he's my brother

He's my brother - he ain't heavy - he's my brother ... .

In this article, we address bystander responsibility from the perspective of the individual in peril. Why and how the individual is in that condition is irrelevant to the recommendation that a duty to act be imposed on the bystander. The circumstances that directly, or indirectly, led to the distress are insignificant to the legal obligation to intervene on behalf of the person in immediate physical peril.

What is important is the distress of one individual - the victim - and the ability of another - the bystander - to mitigate that travail. This is a victimfocused proposal, emphasizing the assistance required by the person in distress and the bystander's capability to provide immediate relief. It is that combination that is essential to understanding the essence of the proposal: distress of person A and capability of person B. While the duty, as we shall discuss, may be mitigated under certain circumstances, the core recommendation entails imposing an obligation to act on the bystander, who does not otherwise owe a legal duty to the person requiring assistance.

\section{A. The Bystander}

The bystander is the person who observes another individual in distress, knows of that person's travail, and has the capability to act on their behalf. The bystander is present at the moment of another person's acute need. The question is whether the bystander will act on behalf of that person or not act by choosing to walk away. Re-stated, will the bystander provide assistance or deliberately and knowingly ignore, thereby committing a crime of omission? Should the bystander choose to walk away, whilst having both the knowledge of the distress of another and the capability to mitigate the harm, the bystander is culpable of a criminal act.

We define assistance narrowly: just dial "911," thereby alerting the authorities as to the dire circumstances of another individual. Adoption of legislation would punish the bystander for failing to provide the victim with concrete assistance. Commensurate with a significant educational undertaking, it would also serve as a deterrent to the broader public: failure to provide assistance to the person in peril will result in criminal prosecution.

Similar legislation has been adopted in ten states and a number of countries,

${ }^{2} I d$ 
reflecting a fundamental re-structuring of the relationship between individuals and significantly extending beyond a moral obligation. ${ }^{3}$ Relying on an aspirational model is, perhaps, satisfying on a basic human level intended to accentuate the basic goodness of people. However, that model does not translate into reality when examined under a bright light on the proverbial operating table.

It is for that reason that we have joined forces with Utah State Representative Brian King, who has twice introduced legislation that defines the failure to call 911 as a Class B Misdemeanor resulting in a \$1,000 fine and/or six months imprisonment. In this article, we analyze both State Rep. King's proposed legislation and criminal codes in other jurisdictions regarding the bystander duty to act obligation. In addition, we examine in detail the hearings before the Utah Judiciary Committee, ${ }^{4}$ which twice voted in favor of State Rep. King's proposal, and the debate on the Floor of the Utah Legislature, which twice voted to defeat the legislation. ${ }^{5}$ We have had significant interaction with legislators, Attorney Generals, and public officials in a number of states and countries considering bystander legislation.

As part of our efforts, we have examined existing bystander legislation in ten U.S. states ${ }^{6}$ and more than two dozen countries ${ }^{7}$ regarding application in those jurisdictions. Our findings are detailed in this article. Furthermore, we have interacted with school officials in a number of states, as educating the broader public regarding the legal obligation to act would be an essential component of the legislative undertaking.

\section{B. Legislation}

The essence of "bystander legislation" is criminalizing the failure to act on behalf of a person in peril. There is no intent to equate the bystander with the perpetrator; the actions of the latter do not equate with the actions or inactions of the former. However, the bystander's decision not to provide assistance enables the actions of the perpetrator. In a historical context, the perpetrators of the Holocaust were enabled by the complicity of the bystander. ${ }^{8}$

\footnotetext{
${ }^{3}$ Do You Have to Rescue Someone in Danger?, BBC News (July 21, 2017), https://www.bbc. com/news/world-us-canada-40680895 [https://perma.cc/Z5H9-FPW7].

${ }^{4}$ Duty to Assist in an Emergency: Hearing on H.B. 125 Before the H. Judiciary Comm., 2018 Leg., 62d Sess. (Utah 2018) [hereinafter Duty to Assist in an Emergency: Hearing on H.B. 125], https://le.utah.gov/av/committeeArchive.jsp?timelineID=105983 [https://perma.cc/S9H2-NP89]; 911 Responsibilities in an Emergency: Hearing on H.B. 170 Before the H. Judiciary Comm., 2019 Leg., 63d Sess. (Utah 2019) [hereinafter 911 Responsibilities in an Emergency: Hearing on H.B. 170], https://le.utah.gov/av/floorArchive.jsp?markerID=106198 [https://perma.cc/T5P7-PR8Q].

${ }^{5}$ Duty to Assist in an Emergency: Hearing on H.B. 125, supra note 4; 911 Responsibilities in an Emergency: Hearing on H.B. 170, supra note 4.

6 Vermont, Washington, Ohio, Minnesota, Wisconsin, Florida, Hawai, Rhode Island, Massachusetts, and California.

${ }^{7}$ Albania, Andorra, Argentina, Austria, Belgium, Brazil, Bulgaria, Croatia, Czech Republic, Denmark, Estonia, Finland, France, Germany, Greece, Hungary, Iceland, Israel, Italy, the Netherlands, Norway, Poland, Portugal, Russia, Serbia, Spain, Switzerland, and Tunisia.

8 See generally Amos N. Guiora, The CRime of Complicity: The Bystander in the HOLOCAUST (2017).
} 
Our motivation in this recommendation is two-fold: to ensure that critical assistance be provided to the victim and to penalize the bystander who failed to act on behalf of that person. In instances of peril resulting from an accident or medical emergency, the obligation to act on behalf of that person is similarly acute. In both instances, the person in distress is in need of assistance.

A casual perusal of the news makes the need for this legislation acutely clear, sometimes painfully so. The constant drumbeat of attacks, sexual and otherwise, emphasize the role of the bystander who knows of the peril of another and yet chooses not to act. In so doing, the bystander becomes complicit in the consequences to the "at risk" individual.

The proposed legislation is predicated on the bystander's physical presence; what is presumed to be seen on social media-Facebook or other platforms - does not impose a duty on the viewer. Given the uncertainty of authenticity regarding events seemingly depicted on social media, extending the duty to act in such circumstances is unwieldly, practically, and legally impractical.

The low bar-dialing 911-imposes a minimal duty on the bystander. There is no demand or expectation, that the bystander physically intervene, whether providing medical assistance or separating individuals involved in a fight. That is not the intention as such actions may have detrimental consequences, either from the perspective of the victim or the bystander. In recommending minimal action, we seek to strike a careful balance: on the one hand, alerting law enforcement; on the other hand, not exposing the bystander to unnecessary harm.

The decision not to intervene is our primary focus. In doing so, we aim to convince the reader of the necessity of bystander legislation, for we are of the belief that criminalizing bystander failure to provide assistance is warranted given the potential consequences of inaction.

\section{Complicity}

Integral to understanding the essence of the bystander's failure to provide assistance is complicity; the two-bystander and complicity - are powerfully, often times tragically, connected. The term "complicity" is not used lightly; it carries with it significant connotations by suggesting the bystander enables harm to the victim and, therefore, shares some of the responsibility. Complicity is ancient but shapes, enables, and permeates contemporary events. It is not by chance that Dictionary.com chose "complicit" as the word of the year in 2017.9 "As 2017 comes to a close, it's time for us to reflect on the words that impacted all of us this year-for better or for worse," Dictionary.com said in announcing its decision. ${ }^{10}$ The online dictionary continued: "[t]he word complicit has sprung up in conversations this year about those who speak out against powerful figures

\footnotetext{
${ }^{9}$ Dictionary.com's 2017 Word of the Year: Complicit, DiCTIONARY.COM, https://www.dictionary. com/e/word-of-the-year-2017/ [https://perma.cc/BU5B-JBBE].

${ }^{10} I d$.
} 
and institutions and about those who stay silent."11

The critical word is "silent"; perhaps more than any other word, it captures the essence of the bystander. The three words-silence, complicity, and bystander - are essential to understanding the consequences to the victim. Tragically, that theme has firm, historical footing: while the evil of the perpetrators of the Holocaust has been thoroughly documented, it is equally important to recall that without the complicity of the bystander, the Nazi regime would not have been able to implement the Final Solution. ${ }^{12}$

A victim is anyone suffering, be it because they find themselves the target of a crime or due to an unfortunate accident or acute health crisis. In criminal situations, a triangular relationship is created between the victim, perpetrator, and bystander.

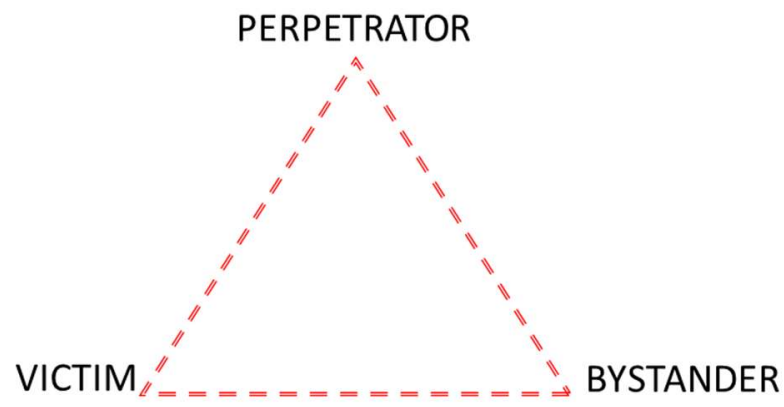

Figure 1

When the victim is in peril due to an accident or health crisis, the relationship between victim and bystander is a straight, linear line.

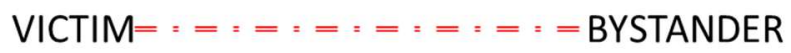

Figure 2

The two constants are the presence of the victim and bystander and the question of whether the latter alleviates the peril of the former. In proposing a victim-oriented approach, we emphasize the consequences of the bystander's decision not to act.

To address these issues, this article will be divided into the following sections: Introduction; Why Bystander Legislation: Whom are We Seeking to Protect and What are We Seeking to Achieve; Literature Survey; Bystander

${ }^{11}$ Amy B. Wang, 'Complicit' Is the 2017 Word of the Year, According to Dictionary.com, WASH. PosT (Nov. 27, 2017, 4:53 PM), https://www.washingtonpost.com/news/the-intersect/wp/2017/ $11 / 27 /$ complicit-is-the-2017-word-of-the-year-according-to-dictionarycom/?utm_term $=.3741 \mathrm{~b} 60 \mathrm{~d}$ dea5 [https://perma.cc/GYF3-MJ8T].

12 "Final Solution"- 1940 to 1945, U.S. Holocaust Memorial Museum, https://www.ushmm .org/information/exhibitions/museum-exhibitions/permanent/final-solution-1940-to-1945 [https:// perma.cc/3YK4-GV4K]. 
Legislation Internationally and in the United States; Application of Bystander Legislation; Our Experiences with the Legislative Process in the State of Utah; Why is Bystander Legislation a Bad Idea?; Going Forward. Directly following Section Seven is an Appendix with the full version of State Rep. King's proposed legislation.

\section{Why Bystander Legislation: Whom are We Seeking to Protect AND WHAT ARE WE SEEKING TO ACHIEVE?}

Efforts to legislate bystander obligation are criticized for a number of reasons reflecting the complexity and controversy inherent in criminalizing most (but not all) inactions. ${ }^{13}$ In broad-brush, to be examined in greater detail in the sections ahead, the primary concerns regarding such legislation focus on fears of prosecutorial abuse of discretion and a belief that bystander obligation is best framed as a moral, rather than a legal, duty. As we shall explain, we beg to differ with these and other concerns raised by proposal opponents. In doing so, we remind readers that our primary focus is on the person in peril, in need of immediate assistance.

The notion of limited duty reflects both political consideration/reality and recognition that a bystander who seeks to do "too much" may, unintentionally, cause harm to the individual in peril. While "Good Samaritan" legislation protects the intervening bystander from legal liability if, in an effort to provide assistance, harm was caused, our analysis is to be distinguished. We do not rely on Good Samaritan legislation in advocating imposing a legal duty on the bystander to act, for we believe the two to be unrelated.

In not requiring actual, physical intervention by the bystander, the proposed model reflects a deliberate effort to strike a careful balance: on the one hand requiring action while, on the other hand, doing so in a manner intended both to minimize risk to the bystander and potential injury to the person in peril. The proposed legislation attempts to strike an applicable/implementable balance between the two individuals who have, regardless of circumstances and conditions, been brought together and share the same space, where the actions of one individual are essential to the welfare of another individual. The sharing of that same space - the physicality of the relationship between the bystander and person in peril-is, for both individuals, a tenuous connection with potentially significant consequences. It is for that reason that the recommended duty is minimal. Nevertheless, provided the bystander meets a two-part test comprised of knowledge and capability, not imposing an obligation to act further enhances the predicament of the individual in distress.

The broader question and more fundamental inquiry is why impose a legal duty rather than relying on a moral foundation reflecting core values of humanity, basic respect, and decency amongst individuals? After all, as the oftquoted phrase suggests, "we know to do the right thing," or as was argued in the

${ }^{13}$ See, e.g., Eugene Volokh, Duties to Rescue and the Anticooperative Effects of Law, 88 GEO. L.J. 105,108 (1999). 
Utah State Legislature, "we in Utah are good people." These arguments are cloaked in anecdotal evidence, community myths, and time-worn clichés.

While, doubtlessly, there are numerous examples of individuals acting on behalf of another in distress, to suggest that is a cultural norm reflecting consistent normative values and behavior is inaccurate. More than that, that oftstated assumption - or perhaps more accurately a reflexive reaction - does not reflect the reality of contemporary society. To rely on the quaint notion that the right thing will be done is "fool's gold" and does not, in the main, provide protection to the individual in distress.

What, then, does bystander obligation legislation seek to achieve that cannot be otherwise attained? More than that, does the presumed benefit of bystander obligation legislation outweigh the costs and consequences of punishing a crime of omission? The primary motivation for the legislative proposal is two-fold: to punish the bystander who fails to provide assistance and to encourage future bystanders to act on behalf of the person in peril. Legislating this obligation is intended to impose a duty that is otherwise not codified, albeit the opposition to criminalizing omission. However, the discomfort that "crimes of omission" inevitably conjure must be weighed against the benefit-to the person in peril-by codifying this duty.

This cost-benefit analysis is integral to understanding the importance and relevance of bystander legislation. Imposing the duty to act, particularly when there is no pre-existing relationship between the person in peril and the bystander, suggests a re-articulation of the Social Contract, for it extends the duty one member of society owes to another. This is distinct from, and in addition to, the Social Contract between the State and the individual as articulated by Rousseau, ${ }^{14}$ Locke, ${ }^{15}$ and Hobbes. ${ }^{16}$

By extending duty to the bystander, the proposed legislation adds a layer of obligation between two individuals who do not have an otherwise pre-existing duty to each other. This is distinct from reporting obligations imposed on teachers or health care providers to children or others who it is suspected are in harm's way. Similarly, this is distinct from a duty a parent owes a child or that of a lifeguard to individuals swimming in a pool. Those duties reflect a professional or contractual obligation, much less the primary duty of a parent or an adult entrusted with the care of a vulnerable child. Those obligations and duties are otherwise codified and largely self-explanatory. The failure to meet those obligations are understandably subject to criminal penalty.

Imposing a duty where there is no pre-existing or contractual duty significantly expands the notion of obligation. That "expansion" must be understood in its intended context: to mitigate the peril of another individual.

\footnotetext{
${ }^{14}$ See generally JEAN-JACQUES ROUSSEAU, DISCOURSE ON THE ORIGIN AND FOUNDATIONS OF INEQUALITY AMONG MEN (Helena Rosenblatt ed., Beford St. Martin's 2011) (1761).

${ }^{15}$ See generally John Locke, Two Treatises OF Government (Peter Laslett ed., Cambridge Univ. Press 1988) (1690).

${ }^{16}$ See generally Thomas Hobbes, Leviathan (J. C. A. Gaskin ed., Oxford Univ. Press 1998) (1651)
} 
The expansiveness is neither abstract nor ephemeral; rather, it is concrete with specific purposes and practical consequences. The extension of "duty owed" to include individuals whose "interaction"-however fleeting-may well be premised on total randomness and happenstance is to restructure the concept of obligation and responsibility. More than that: the two individuals - the person in distress and the bystander-possibly do not exchange a word or glance and, in all probability, do not know each other's name. That, however, is irrelevant to the duty we seek to impose on the bystander.

This is, then, a matter of trade-offs: imposition of duty on the bystander, potentially resulting in punishment, in exchange for providing assistance, of a limited nature, to a person in distress. The proposed duty-limited to dialing 911 -intends to fill an important gap in the criminal code of a number of jurisdictions.

\section{LITERATURE SURVEY}

Under the common law, there is no legal duty to act on behalf of anyone in peril. Scholarly discussions have reached different conclusions regarding the merits of creating such a legislative requirement. ${ }^{17}$

Those who favor the common law tradition argue that imposing liability for failing to prevent harm runs contrary to principles of personal autonomy. ${ }^{18}$ This argument focuses on the difference between directly causing harm and simply failing to prevent it. ${ }^{19}$ That is, our criminal law system requires an element of causation in order to respect one's personal autonomy; we are responsible for the consequences of our own actions but not the actions of others. Here, the fear is that duty to assist laws will "strong arm individuals to act in situations where their conscience should be their guides." 20

The inverse criticism of bystander liability argues that it does not materially affect behavior and is thus not worth pursuing. Scholars point to existing legislation, arguing that the laws on the books have not been enforced with any regularity or consistency. ${ }^{21}$ This view dismisses the idea of bystander liability, describing duty to assist laws as "easily made but rarely enforced." 22

The relationship between a bystander's ability and decision to assist has evolved with the rising power of social media and overall technological

\footnotetext{
${ }^{17}$ Melody J. Stewart, How Making the Failure to Assist Illegal Fails to Assist: An Observation of Expanding Criminal Omission Liability, 25 AM. J. CRIM. L. 385, 387 (1998); Arthur Alan Severance, The Duty to Render Assistance in the Satellite Age, 36 CAL. W. INT'L L.J. 377, 399 (2006); Patricia Grande Montana, Watch or Report? Livestream or Help? Good Samaritan Laws Revisited: The Need to Create a Duty to Report, 66 CLEV. ST. L. REV. 533, 536 (2018); Marcia M. Ziegler, Nonfeasance and the Duty to Assist: The American Seinfeld Syndrome, 104 DICK. L. REV. $525,528(2000)$.

${ }^{18}$ Ziegler, supra note 17, at 536.

${ }^{19} \mathrm{Id}$.

${ }^{20}$ Stewart, supra note 17 , at 423 .

${ }^{21} \mathrm{Id}$. at 424 .

${ }^{22} I d$.
} 
advances. ${ }^{23}$ Technology may also have created a desensitization to violence and a decrease in empathy, which make it more likely for bystanders to pull out their phones to film an incident rather than dial $911 .^{24}$

There are arguments that statutes requiring a duty to act are ineffective and do not materially alter behavior. ${ }^{25}$ This is based on social and physiological research, which demonstrates that fear of prosecution does not compel action from those who otherwise feel no responsibility to assist a stranger in peril. ${ }^{26}$ Instead, commentators claim many recent laws have been the result of emotional public responses to violent crimes but are not based on logic or function. ${ }^{27}$ In short, these commentators describe recent legislative action as "feel good legislation," which ignores possible adverse consequences and will not actually make a difference in the frequency of a particular crime. ${ }^{28}$

Citing this lack of effectiveness, critics pose various possible adverse consequences and insist that they outweigh any benefit. One difficulty may lie in evaluating whether someone is genuinely in danger or the degree to which an easy rescue is possible, which may, in turn, result in unjust convictions. ${ }^{29}$ Another consequence may arise from a vague statute that could allow prosecutors to bring frivolous charges and allow convictions to be based on the "public moral outrage." 30

A separate criticism is that an affirmative duty to act may encourage reckless attempts to rescue victims of crime. ${ }^{31}$ Critics assert that this will only exacerbate the situation by putting the would-be-rescuer in just as much danger as the victim. ${ }^{32}$ Under this view, preventing crime is best left to law enforcement professionals. ${ }^{33}$

Further concerns focus on potential adverse consequences for those providing assistance. A legal requirement to assist could result in personal consequences in the form of legal retribution for failing to comply with that duty, or injury from voluntarily engaging in a dangerous situation. ${ }^{34}$ It is difficult for some critics to accept the idea that there are individuals who should face consequences for their inaction. ${ }^{35}$ The general theme underlying these concerns

${ }^{23}$ Montana, supra note 17 , at 536.

${ }^{24}$ Amelia J. Uelmen, Crime Spectators and the Tort of Objectification, 12 U. MASS. L. REV. 68, 76 (2017).

${ }^{25}$ Justin T. King, Criminal Law: “Am I My Brother's Keeper?” Sherrice's Law: A Balance of American Notions of Duty and Liberty, 52 OKLA. L. REV. 613, 628 (1999).

${ }^{26}$ Stewart, supra note 17 , at 428 .

${ }^{27} I d$. at 422.

${ }^{28} I d$.

${ }^{29}$ Jay Logan Rogers, Testing the Waters for an Arizona Duty-to-Rescue Law, 56 ARIZ. L. REV. 897, 907 (2014).

${ }^{30} I d$. at 910 .

${ }^{31}$ Id. at $908-09$.

${ }^{32} I d$.

${ }^{33} I d$. at 909 .

${ }^{34}$ Andrew D. Kaplan, "Cash-Ing Out": Regulating Omissions, Analysis of the Sherrice Iverson Act, 26 New EnG. J. ON CRIM. \& Civ. CONFINEMENT 67, 82 (2000).

${ }^{35} \mathrm{Id}$. 
is that bystander legislation diminishes free agency and that an individual should only be held accountable for their affirmative actions. ${ }^{36}$

Scholars have also argued that "duty-to-assist laws 'go beyond the appropriate realm of criminal liability and into the sphere of moral accountability." "37 Under this view, an encouragement of altruistic behavior is the answer. ${ }^{38}$ Such scholars point to "the moral compass," arguing that people in our society feel an obligation to help those in need, and that such behavior need not be legally mandated..$^{39}$ Instead, the requirement to extend assistance to others should be forwarded by other social institutions, such as religion. This commentary asserts that the moral duty to assist will continue to be enforced by the potential reproach of "good people" in our society. ${ }^{40}$

In contrast, other scholars take issue with the rigid nature of the law that prevents imposing liability on those who witness crime and do nothing. ${ }^{41}$ These commentators support bystander liability and make various arguments to forward their claims. One obvious argument is that such laws provide an incentive to help strangers in peril, which will prevent crime and protect victims. ${ }^{42}$ Further, some argue that duty to assist laws reflect the general views of our society. ${ }^{43}$

For example, Marcia M. Ziegler urges legislatures around the country to create a uniform duty to assist law consistent with what society already considers reasonable. ${ }^{44}$ She asserts that the traditional rule eliminating liability for "failing to act" operates as an exception to the widespread duty to act as a reasonably prudent person would under the circumstances. ${ }^{45}$ That is, the lack of a duty to assist is essentially a "get out of jail free" pass that operates contrary to society's collective sense of morality and logic. ${ }^{46}$ Ziegler proposes statutory language that would codify what society already considers reasonable to put unreasonable people on notice that their behavior is likely to result in liability ${ }^{47}$ She argues that duty to assist statutes have the potential to prevent suffering and, at the very least, would create liability for those who are responsible. ${ }^{48}$

Proponents of this view note that the law already imposes an affirmative duty to act in various situations, reflecting society's views. Those duties are designed to prevent instances such as drunk driving deaths and child abuse and

\footnotetext{
${ }^{36} \mathrm{Id}$. at 71 .

${ }^{37}$ Stewart, supra note 17 , at 433 .

${ }^{38} I d$. at $432-33$.

${ }^{39} I d$.

${ }^{40} \mathrm{Id}$.

${ }^{41}$ Breanna Trombley, Criminal Law-No Stitches for Snitches: The Need for a Duty-to-Report Law in Arkansas, 34 U. ARK. LiTTLE Rock L. REV. 813, 815-16 (2012).

${ }^{42}$ Rogers, supra note 29, at 902.

${ }^{43} I d$. at 903.

${ }^{44}$ Ziegler, supra note 17, at 556.

${ }^{45} I d$. at 539.

${ }^{46} \mathrm{Id}$. at 555 .

${ }^{47} \mathrm{Id}$. at 556

${ }^{48}$ Id. at $559-60$.
} 
to make sure people enforce and respect pre-existing contractual agreements. ${ }^{49}$ Essentially, the argument is that laws already exist and have evolved to impose duties to behave in a way that conforms to societal standards; therefore, no further legislative adjustments are required.

Commentators also suggest that many of the adverse consequences posed by critics may be mitigated by the language of the statute. For example, most of the relevant statutes contain exceptions that apply in circumstances where assistance would cause danger for the person providing assistance or for third parties. ${ }^{50}$ Some also note that the duty imposed can be very narrow. One way to narrow the statute would be to explicitly state that it would apply only in situations where the bystander knows that a person is exposed to or has suffered grave physical harm. ${ }^{51}$

Other ways in which bystander legislation can, and has, been limited is through language which specifies that the duty will be fulfilled by simply attempting to obtain aid from law enforcement or medical personnel, such as simply dialing $911 .{ }^{52}$ Language which narrows such legislation has also focused on created limits to the potential liability for those who violate the duty to assist. There are suggestions that bystander statutes should specifically limit the possible liability to low level offenses or the imposition of small fines. ${ }^{53}$ In other words, the idea is to create a statute that acts as "more of a nudge than a shove." 54

\section{BYSTANDER LEGISLATION INTERNATIONALLY AND IN THE UNITED STATES}

Some states and several countries, despite their differing legal structures and historical backgrounds, have arrived at similar conclusions: that their society would benefit from the implementation of some form of bystander legislation. The American legal system traces its roots to the early seventeenth century, when English settlers brought the common law and practices of the English system. ${ }^{55}$ England has of yet, never codified a duty to assist, refusing to place a legal liability upon the failure to act.

In writing the majority opinion for the House of Lords (comparable to an American Court of Appeals), Lord Hoffman addressed the types of duties that individuals, acting as members of society, owe to one another:

One can put the matter in political, moral or economic terms. In political terms it is less of an invasion of an individual's freedom for the law to require him to consider the safety of others in his actions

${ }^{49} I d$. at 555.

${ }^{50}$ Rogers, supra note 29, at 918-19.

${ }^{51} I d$. at 919 .

${ }^{52} \mathrm{Id}$.

${ }^{53} \mathrm{Id}$.

${ }^{54} I d$. at 920.

${ }^{55}$ Selena E. Molina, The Roots of Our Legal System: The Foundation for Growth, A.B.A. (2017), https://www.americanbar.org/groups/young_lawyers/publications/tyl/topics/legal-history/roots-ou r-legal-system-foundation-growth/ [https://perma.cc/W3WS-8UL3]. 
than to impose upon him a duty to rescue or protect. A moral version of this point may be called the 'Why pick on me?' argument. ${ }^{56}$

The American judiciary chose to follow English precedence. Courts will only recognize that bystanders have certain duties: imposed legislatively; contractually; situations where parties have a special relationship to one another; or in instances where an individual creates a hazardous situation that places another individual in danger, which would place a duty to rescue upon the individual who created the hazard. ${ }^{57}$

In 1898, New Hampshire's Chief Justice of the Supreme Court articulated the common law standard with the following illustrative scenario:

Suppose A., standing close by a railroad, sees a two-year-old babe on the track, and a car approaching. He can easily rescue the child, with entire safety to himself, and the instincts of humanity require him to do so. If he does not, he may, perhaps, justly be styled a ruthless savage and a moral monster; but he is not liable in damages for the child's injury, or indictable under the statute for its death. ${ }^{58}$

The Chief Justice was correct, and while the court of moral opinion might label a man who declines to save a child's life as a "monster," the "mere moral obligation" to act is outside the scope of traditional legally reprehensible civil or criminal behavior. ${ }^{59}$

For decades, it remained true that "[n]o action will lie against a spiteful man, who, seeing another running into danger, merely omits to warn him." 60 Then, in 1967, Vermont became the first state to pass bystander legislation, and other states shortly began to follow suit. In a little over three decades, ten states passed duty to assist laws. The strength and subject matter of these laws vary from state to state.

${ }^{56}$ Stovin v. Wise [1996] 3 All ER 801 (HL) 819 (appeal taken from Eng.).

${ }^{57}$ Dan B. Dobbs, Paul T. Hayden \& Ellen M. Bublick, The Law Of Torts $\S 405$ (2d ed. 2011).

${ }^{58}$ Buch v. Armory Mfg. Co., 44 A. 809, 810 (N.H. 1898).

${ }^{59}$ People v. Beardsley, 113 N.W. 1128, 1129 (Mich. 1907).

${ }^{60}$ Gautret v. Egerton, L.R. 2 C.P. 371, 375 (1867). 


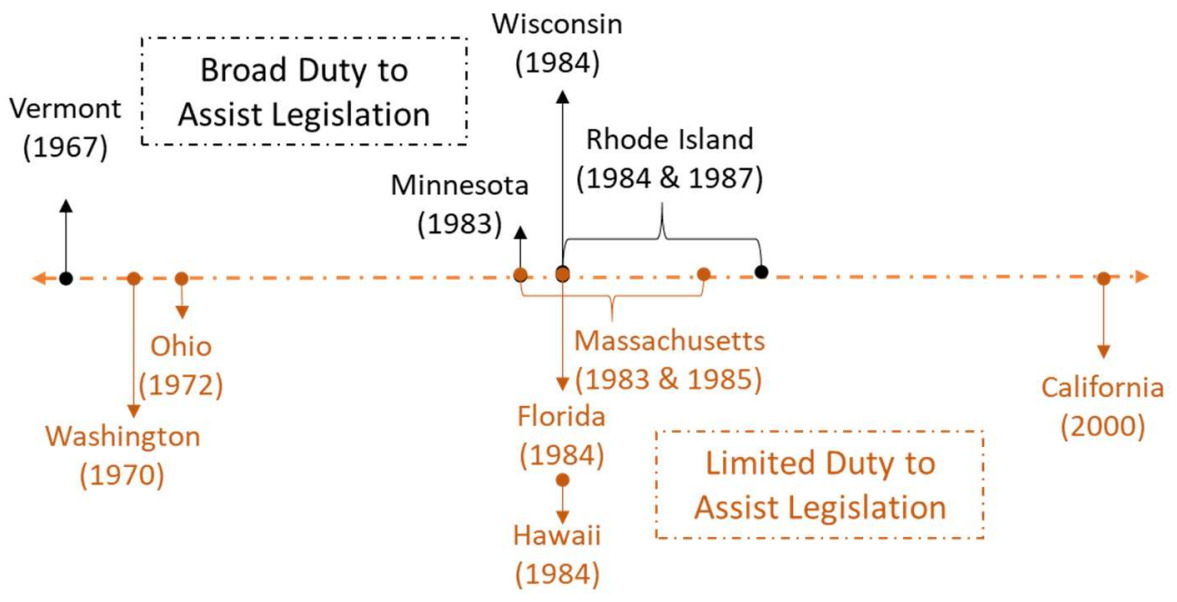

Figure $3^{61}$

Of the states that have imposed an affirmative duty upon bystanders, with no relation to the victim, only four have broad duty to assist laws that require action by any person at the scene of any emergency, regardless of the crime, or the victim. ${ }^{62}$ Vermont's innovative legislation has some of the broadest statutory language:

(a) A person who knows that another is exposed to grave physical harm shall, to the extent that the same can be rendered without danger or peril to himself or herself or without interference with important duties owed to others, give reasonable assistance to the exposed person unless that assistance or care is being provided by others.

(b) A person who provides reasonable assistance in compliance with subsection (a) of this section shall not be liable in civil damages unless his or her acts constitute gross negligence or unless he or she will receive or expects to receive remuneration. Nothing contained in this subsection shall alter existing law with respect to tort liability of a practitioner of the healing arts for acts committed in the ordinary course of his or her practice.

(c) A person who willfully violates subsection (a) of this section shall

\footnotetext{
${ }^{61}$ Vt. Stat. AnN. tit. 12, § 519 (West 1967); WASh. ReV. Code AnN. § 9.69.100 (West 1970); OHIO Rev. CODE ANN. § 2921.22 (West 1972); MinN. StAT. ANN. § 604A.01 (West 1983); MASS. GEN. LAWS ANN. ch. 268, § 40 (West 1983); WiS. STAT. ANN. § 940.34 (West 1984); FLA. STAT. ANN. § 794.027 (West 1984); HAW. REV. STAT. ANN. § 663-1.6 (West 1984); 11 R.I. GEN. LAWS ANN. § 11-56-1 (West 1984); MASS. GEN. LAWS ANN. ch. 269, § 18 (West 1985); 11 R.I. GEN. LAWS ANN. § 11-1-5.1 (West 1987); CAL. PENAL CODE $§ 152.3$ (West 2000).

${ }^{62}$ VT. Stat. AnN. tit. 12, § 519 (West 1967); Minn. StAT. AnN. § 604A.01 (West 1983); Wis. STAT. ANN. § 940.34 (West 1984); 11 R.I. GEN. LAWS ANN. § 11-56-1 (West 1984).
} 
be fined not more than $\$ 100.00 .^{63}$

The six states with limited bystander legislation have statutory language that limits its application to either a specific category of victim or a specific type of crime.

\begin{tabular}{|c|c|c|c|}
\hline STATE & MANDATORY REPORTING & CRIME & PENALTY \\
\hline California & $\begin{array}{l}\text { Only victims of rape and murder } \\
\text { that are } 14 \text {-years-old or younger }\end{array}$ & Misdemeanor & $\begin{array}{l}\text { Up to } 6 \text { months in prison, } \\
\$ 1500 \text { fine, or both }\end{array}$ \\
\hline Florida & Only victims of sexual battery & $\begin{array}{l}1^{\text {st }} \text { Degree } \\
\text { Misdemeanor }\end{array}$ & Up to 1 year in jail \\
\hline Hawaii & Only victims of crimes & $\begin{array}{l}\text { Petty } \\
\text { Misdemeanor }\end{array}$ & $\begin{array}{l}\text { Up to } 30 \text { days in jail and a } \\
\text { fine up to } \$ 1000\end{array}$ \\
\hline Massachusetts & $\begin{array}{l}\text { Only victims of rape, murder, } \\
\text { manslaughter, armed robbery, or } \\
\text { hazing }\end{array}$ & Misdemeanor & $\begin{array}{l}\$ 500-\$ 2500 \text { fine (or up to } \\
\$ 1000 \text { fine as to hazing) }\end{array}$ \\
\hline Minnesota & Any crime and any victim & $\begin{array}{l}\text { Petty } \\
\text { Misdemeanor }\end{array}$ & Up to $\$ 300$ fine \\
\hline Ohio & $\begin{array}{l}\text { Only if a felony has been or will } \\
\text { be committed }\end{array}$ & $\begin{array}{l}4^{\text {th }} \text { Degree } \\
\text { Misdemeanor }\end{array}$ & $\begin{array}{l}\text { Up to } 30 \text { days in jail and a } \\
\text { fine up to } \$ 250\end{array}$ \\
\hline Rhode Island & Any crime and any victim & Misdemeanor & $\begin{array}{l}\text { Up to } 6 \text { months in prison, } \\
\$ 500 \text { fine, or both }\end{array}$ \\
\hline Vermont & Any crime and any victim & Infraction & Up to $\$ 100$ fine \\
\hline Washington & $\begin{array}{l}\text { Only victims of violent offenses, } \\
\text { sexual abuse, or assault of a child }\end{array}$ & $\begin{array}{l}\text { Gross } \\
\text { Misdemeanor }\end{array}$ & $\begin{array}{l}\text { Up to } 364 \text { days in jail and } \\
\text { a fine up to } \$ 5000\end{array}$ \\
\hline Wisconsin & Any crime and any victim & $\begin{array}{l}\text { Class C } \\
\text { Misdemeanor }\end{array}$ & $\begin{array}{l}\text { Up to } 30 \text { days in jail and a } \\
\text { fine up to } \$ 500\end{array}$ \\
\hline
\end{tabular}

Figure $4^{64}$

Florida's statute, for example, criminalizes only the failure to report sexual battery while remaining silent about those who choose to ignore victims facing any other form of peril. ${ }^{65}$ In 2017, a handicapped adult male drowned in Florida while a group of teens mocked him and filmed him on their cell phones; once the man stopped struggling and failed to resurface, the onlookers remarked "oh he just died" and departed the scene that was no longer entertaining, and uploaded the video to the internet, no doubt to gain some notoriety with a viral

${ }^{63}$ VT. STAT. ANN. tit. 12, § 519 (West 1967).

${ }^{64}$ See generally Mandatory Reporters of Child Abuse and Neglect, CHILDREN's BUREAU (Apr. 2019), https://www.childwelfare.gov/pubPDFs/manda.pdf [https://perma.cc/R7CB-XDZV]; VT. StAT. ANN. tit. 12, § 519 (West 1967); WASH. ReV. CODE ANN. § 9.69.100 (West 1970); OHIO ReV. Code ANN. § 2921.22 (West 1972); MinN. StAT. ANN. § 604A.01 (West 1983); MASS. GEN. LAWS ANN. ch. 268, § 40 (West 1983); Wis. STAT. ANN. § 940.34 (West 1984); Fla. STAT. ANN. $\S 794.027$ (West 1984); HAW. REV. STAT. ANN. § 663-1.6 (West 1984); 11 R.I. GEN. LAWS ANN. $\S 11-56-1$ (West 1984); MASS. GEN. LAWS ANN. ch. 269, § 18 (West 1985); 11 R.I. GEN. LAWS ANN. § 11-1-5.1 (West 1987); CAL. PENAL CODE $§ 152.3$ (West 2000).

${ }^{65}$ FLA. STAT. ANN. $§ 794.027$ (West 1984). 
video ${ }^{66}$ No Florida law was broken.

In 1997, in Las Vegas, nineteen-year-old David Cash Jr. watched his friend sexually assault seven-year-old Sherrice Iverson in a public restroom. ${ }^{67}$ When Cash later asked his friend what happened to the child, his friend said he had killed her. ${ }^{68}$ Cash never reported the rape and murder of the child ${ }^{69}$ Sherrice's mother began a petition, asking authorities to hold Cash legally accountable for his inaction. ${ }^{70}$ The district attorney assigned to the case stated that, regrettably, she could not hold Cash accountable in a court of law; only the court of public opinion could render judgment. ${ }^{71}$

Sherrice's murder - and other acts of violence towards children - brings into question the capacity of safeguards that may or may not exist in each jurisdiction. Every state has created a list of professionals who are legally mandated to report the neglect or abuse of a child. ${ }^{72}$ States differ when it comes to which bystanders must act when they know that a child is being abused or neglected. Some legislation has language where others may report child abuse, and others where individuals must report child abuse. ${ }^{73}$

${ }^{66}$ Do You Have to Rescue Someone in Danger?, supra note 3; CBS Worldwide, Inc., The Bad Samaritan Part 1 of 2 (1998), YouTuBE (Aug. 2, 2009), https://www.youtube.com/watch?v=KqTd XOQmXrc [https://perma. cc/EF46-E8PE].

${ }^{67}$ Don Terry, Mother Rages Against Indifference, N.Y. TIMES (Aug. 24, 1998), https://www.ny times.com/1998/08/24/us/mother-rages-against-indifference.html [https://perma.cc/7A2S-68Q5].

${ }^{68} I d$.

${ }^{69} \mathrm{Id}$.

${ }^{70} I d$.

${ }^{71} \mathrm{Id}$.

${ }^{72}$ Mandatory Reporters of Child Abuse and Neglect, supra note 64, at 2.

${ }^{73} \mathrm{Id}$. 
Below is a map of the states with a "may report" legal standard: ${ }^{74}$

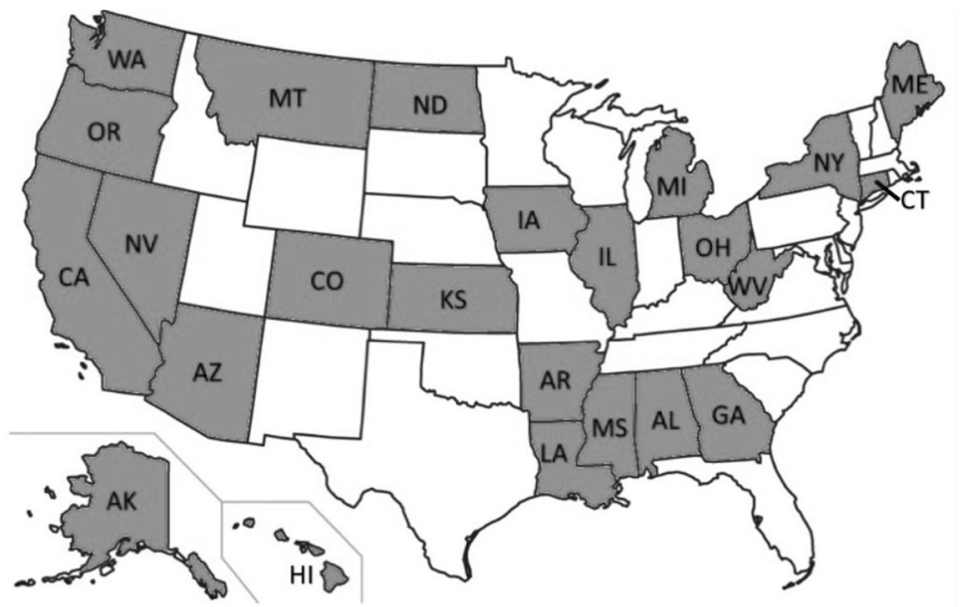

Figure 5

In each of the gray states, there is no legal requirement for an individual to report the neglect or abuse of a child if that individual has no identifiable relationship to that child. ${ }^{75}$ In other words, Cash would still face no legal consequences for his role in the murder of Sherrice Iverson in any of these states.

Variations of legal requirements for bystanders to assist individuals in distress have been enacted in Albania, Andorra, Argentina, Austria, Belgium, Brazil, Bulgaria, Croatia, Czech Republic, Denmark, Estonia, Finland, France, Germany, Greece, Hungary, Iceland, Israel, Italy, the Netherlands, Norway, Poland, Portugal, Russia, Serbia, Spain, Switzerland, and Tunisia. ${ }^{76}$

Legislation in each country differs in its construction as well as its application. One example is French Penal Code 223-6, which reads:

Any person who willfully abstains from rendering assistance to a person in peril when he or she could have rendered that assistance without risk to himself, herself, or others, either by acting personally or by calling for aid, is liable to the same penalties [i.e., five years imprisonment and a 500,000 francs fine]. ${ }^{77}$

An example of bystander legislation application arose from an incident that took place in October 2016, when an eighty-three-year-old man collapsed at the

${ }^{74} \mathrm{Id}$.

${ }^{75} \mathrm{Id}$.

${ }^{76}$ See generally Criminal Codes, LEGISLATIONLINE, https://www.legislationline.org/documents/ section/criminal-codes/country/46/Albania/show [https://perma.cc/N92Q-7KTQ].

${ }^{77}$ Edward A. Tomlinson, French Experience with Duty to Rescue: A Dubious Case for Criminal Enforcement, 20 N.Y.L. SCH. J. INT'L \& COMP. L. 451, 460-61 (2000) (citing the 1994 French Penal Code [C. PÉN.] [PENAL CODE] art. 223-6 (Fr.)). 
entryway of a bank in Germany and not one, not two, but three people stepped over the man to use the ATM. ${ }^{78}$ The incident was captured by a surveillance camera and was used in court to show the indifference bystanders showed towards the elderly man, who died a week after his collapse at the bank. ${ }^{79}$ The three bystanders were convicted and required to pay fines, ranging from $\$ 2,900$ to $\$ 4,300$, for failing to assist the man, which was a direct violation of German law. ${ }^{80}$ By holding these individuals accountable for their callous indifference, Germany sent a message to all its citizens that they are held to a higher standard; if there is suffering and something can be done, something should be done.

\section{APPLICATION OF BYSTANDER LEGISLATION}

Two contrasting criticisms of bystander legislation address its application: it will lead to a flood of litigation, and, if the crime is indeed difficult to prove, no one will be charged under the statute making its enactment a waste of time. The inherent complication with answering these types of questions is that there is no single system, nationally or at the state level, that can track how and when a certain piece of legislation is used. Therefore, in an attempt to address whether either of these criticisms have merit, we contacted approximately 450 courthouses from the ten states that have such legislation.

Less than half of these courthouses responded; approximately sixty percent of those who responded indicated that their system could not access the requested information. ${ }^{81}$ However, from the courthouses that could access the information, almost no instances were reported of individuals being charged under their state's bystander legislation. The few instances where individuals were charged with failure to report indicates that the legislation has not proven useless while also affirming that, following its enactment, it did not lead to an untenable amount of litigation.

We also used a broader method to analyze the frequency of legislation use by examining all reported cases on Lexis and Westlaw. The limitations with this method are that each site only lists those appellate cases which have been reported. The following information was gathered from the two websites: ${ }^{82}$

\footnotetext{
${ }^{78}$ Cassandra Santiago \& Stephanie Halasz, Germany Convicts 3 for Not Helping an Elderly Man Who Collapsed, CNN (Sept. 19, 2017, 12:40 PM), https://www.cnn.com/2017/09/19/europe/ germany-good-samaritan-case-trnd/index.html [https://perma.cc/5TF7-FNQX].

${ }^{79} I d$.

${ }^{80} I d$.

${ }^{81}$ Survey Findings of Reported Appellate Cases Dealing with Criminal Charges based on "Duty to Report" Legislation (August 2019) (unpublished findings) (on file with authors at the S.J. Quinney College of Law, University of Utah) (using Westlaw and Lexis databases).

${ }^{82}$ Id.
} 


\begin{tabular}{|c|c|c|}
\hline STATE & $\begin{array}{l}\text { CRIMINAL } \\
\text { CHARGES }\end{array}$ & OUTCOMES \\
\hline Vermont (1967) & 0 & ---- \\
\hline Washington (1970) & 0 & ----- \\
\hline Ohio (1972) & 1 & Conviction overturned \\
\hline Minnesota (1983) & 0 & ----- \\
\hline Florida (1984) & 0 & ----- \\
\hline Hawaii (1984) & 3 & $\begin{array}{c}\text { All upheld (each charge was } \\
\text { combined with more severe } \\
\text { offenses) }\end{array}$ \\
\hline $\begin{array}{l}\text { Massachusetts } \\
\text { (1983 \& 1985) }\end{array}$ & 0 & ----- \\
\hline Wisconsin (1984) & 4 & $\begin{array}{c}\text { All upheld ( } 2 \text { of the } 4 \text { were } \\
\text { combined with more severe } \\
\text { offenses) }\end{array}$ \\
\hline $\begin{array}{l}\text { Rhode Island } \\
\text { (1984 \& 1987) }\end{array}$ & 0 & ----- \\
\hline California (2000) & 0 & ----- \\
\hline
\end{tabular}

Figure 6

The scarce number of appellate cases may be an indication that the ramifications are so insignificant that individuals would rather not waste time and money to appeal, that there are not many prosecutions to begin with, or that the prosecutions under these laws are only undertaken when there is extremely solid evidence and high likelihood of conviction.

The approaches that Courts have taken when addressing these cases are more crucial to understanding this type of legislation than the percentages of use or frequencies of litigation. Legislators have indicated that amongst their biggest concerns with bystander legislation is its application. ${ }^{83}$ The type of impact that legislation will have on a community is vitally important, and, for some legislators, it is the only factor worthy of consideration when discussing newly proposed bills. ${ }^{84}$

In assessing the impact that a specific legislation has had, the traditional approach is to look at court cases and scholarly assessments. The application of duty to assist legislation has proved difficult to analyze for two reasons. First,

${ }^{83}$ Duty to Assist in an Emergency: Hearing on H.B. 125, supra note 4; 911 Responsibilities in an Emergency: Hearing on H.B. 170, supra note 4.

${ }^{84}$ Duty to Assist in an Emergency: Hearing on H.B. 125, supra note 4; 911 Responsibilities in an Emergency: Hearing on H.B. 170, supra note 4. 
there are only ten states with duty to assist legislation, with varying degrees of coverage, and many have only been on the books for a few decades; ${ }^{85}$ therefore, case law is limited on this subject. Secondly, due to the lack of cases available to analyze, most scholarly works can only address the subject from a theoretical perspective.

Specific applications of these statutes by courts has proven to be the best indicator of their real-world effect. Misinterpretation of these statutes often has individuals imagining that it requires direct intervention of bystanders. ${ }^{86}$ The Supreme Court of Vermont specifically indicated that their duty to assist "does not create a duty to intervene in a fight." 87 If the situation presents "danger or peril" to the rescuer, then Vermont's statute prevents a duty from arising. ${ }^{88}$

In Washington, the attempt to elevate the failure to report a violent offense to support a manslaughter charge was rejected by the State Supreme Court. ${ }^{89}$ Such legislation was used to increase criminal charges in Hawaii after two-yearold Natasha was beaten and then later succumbed to her wounds because neither her mother, nor her mother's boyfriend, sought medical assistance. ${ }^{90}$ The circumstances surrounding Natasha's death made it difficult to tie a specific individual to her injuries as the defendants claimed that several individuals had access to, and could have beaten, the child on the day that she died. ${ }^{91}$ Unable to tie Natasha's injuries to an individual's affirmative actions, the court held that the mother and boyfriend, who knew of the child's condition and failed to obtain medical care, recklessly caused the child's death. ${ }^{92}$

In every state, parents are statutorily bound to protect their children and seek medical attention when necessary; ${ }^{93}$ however, the mother's boyfriend had no legal connection to the child. Absent additional statutory requirements, the boyfriend would have gone free, despite proof he knew the child was in critical condition and evidence to suggest that he likely had a hand in inflicting those injuries. Hawaii passed legislation twenty years prior to the incident which provides that "[a]ny person at the scene of a crime who knows that a victim of the crime is suffering from serious physical harm shall obtain or attempt to obtain aid from law enforcement or medical personnel." 94 The boyfriend's

${ }^{85}$ VT. STAt. ANN. tit. 12, § 519 (West 1967); WASH. Rev. CodE ANN. § 9.69.100 (West 1970); OHIO REv. CODE ANN. $§ 2921.22$ (West 1972); MinN. STAT. ANN. § 604A.01 (West 1983); MASS. GEN. LAWS ANN. ch. 268, $\S 40$ (West 1983); Wis. StAT. ANN. $§ 940.34$ (West 1984); Fla. STAT. ANN. § 794.027 (West 1984); HAW. REV. STAT. ANN. § 663-1.6 (West 1984); 11 R.I. GEN. LAWS ANN. § 11-56-1 (West 1984); MASS. GEN. LAWS ANN. ch. 269, § 18 (West 1985); 11 R.I. GEN. LAWS ANN. § 11-1-5.1 (West 1987); CAL. PENAL Code $\S 152.3$ (West 2000).

${ }^{86}$ Duty to Assist in an Emergency: Hearing on H.B. 125, supra note 4; 911 Responsibilities in an Emergency: Hearing on H.B. 170, supra note 4.

${ }^{87}$ State v. Joyce, 433 A.2d 271, 273 (Vt. 1981).

${ }^{88} \mathrm{Id}$.

${ }^{89}$ State v. Sublett, 292 P.3d 715, 728 (Wash. 2012).

${ }^{90}$ State v. Faufata, 66 P.3d 785, 793-94 (Haw. Ct. App. 2003).

${ }^{91} I d$. at 793.

${ }^{92} \mathrm{Id}$. at $796-97$.

${ }^{93}$ Baruch Gitlin, Annotation, Parents' Criminal Liability for Failure To Provide Medical Attention to Their Children, 118 A.L.R. 5th 253 (2004).

${ }^{94}$ HAW. REV. STAT. ANN. § 663-1.6 (West 1984). 
attempt to escape liability failed and, despite his sentence being lessened due to an absence of evidence of criminal commissions, was punished for his criminal commissions. ${ }^{95}$

Given the importance of the effect that legislation has on a community, it is critical to include in the discussion any instances where similar laws have been enforced in other jurisdictions before passing new laws. These discussions themselves often help courts determine the manner in which a statute should be interpreted because, if there is uncertainty as to a statute's meaning, justices may look to "the legislative history of the measures and statements" by those who were in charge of the statute during its consideration. ${ }^{96}$ Careful craftmanship and thoughtful conversation is perhaps the singularly best way to ensure that new legislation is used exclusively in situations for which it was designed.

\section{OUR EXPeriences WITH The Legislative Process in the State of UTAH}

While the Utah Legislature has yet to ratify State Rep. King's "911 Responsibilities in an Emergency" legislation, ${ }^{97}$ our experiences shed invaluable light on the complexity of the legislative process with matters that intersect morality and legality. It is that complicated space that the question of bystander duty occupies; there is a sense of "cross-over" that casts doubt for some legislators on the viability of legislating what some refer to as "the right thing to do." While other arguments were voiced in opposition to the proposed legislation, it is this question - more than any other-that raises the greatest concern for legislators. The question is "why?", and what do we learn from that?

In focusing on the morality-legality confluence, it seems that a preliminary question that is glossed over, yet deserves our utmost attention since it is the core of the proposal, is how to frame the duty owed by person A to person B when there is no pre-existing relationship or otherwise legislated duty. This requires the creation of a duty between two individuals who do not know each other, when the person in peril is neither a child nor elderly. This caveat is relevant because in Utah, duty laws were enacted by the legislature applying to vulnerable children and the elderly. ${ }^{98}$

State Rep. King's legislation can be perceived as an "add-on" to duty requirements that the Legislature previously codified. It is that "extra step"extending existing obligations - that has proven particularly vexing. State Rep. King's legislation would extend the existing duty requirement-a seemingly logical measure - to a category not presently defined as vulnerable: individuals in peril, incapable of the simple act of dialing 911, as that is the sole obligation State Rep. King's legislation imposes on the bystander.

The victim - presently outside existing protected categories of children or the elderly - has no special characteristics and no connection to the person

\footnotetext{
${ }^{95}$ State v. Martinez, 68 P.3d 606, 612, 617 (Haw. 2003).

${ }^{96}$ United States v. Great N. Ry. Co., 287 U.S. 144, 154 (1932).

${ }^{97}$ H.B. 170, 2019 Leg., 63d Sess. (Utah 2019).

${ }^{98}$ UTAH CODE ANN. § 62A-4a-403 (West 2018); UTAH CODE ANN. § 62A-3-305 (West 2012).
} 
positioned to provide the minimal assistance to alleviate the peril. In other words, there is neither a pre-existing duty nor a pre-existing relationship between the victim and the person positioned to alleviate distress. The intent of State Rep. King's legislation to protect falls into a space outside specially designated and protected zones. It is that category, devoid of special characteristics and unique qualities, that - as we learned over the past two years during meetings, discussions, and hearings - has proved the most challenging for legislators to recognize as also being vulnerable and in need of assistance when in peril. That, for lack of a better term, "middle category," if not in peril at a particular moment would not require assistance is one that the legislature has proved unwilling to impose as a requirement on the bystander to intervene on their behalf when circumstances clearly dictate "help needed."

While legislators acknowledge there are instances when individuals in distress require assistance, they reference the "right thing to do" argument, reflecting a conclusion that the bystander will be sufficiently morally grounded. ${ }^{99}$ It is an argument, actually a refrain, that seemingly "soothes the soul" of the speaker, reflecting a belief in the basic goodness of humanity, and assuming that victims in peril can rely on this model. Similarly, those that ascribe to this school of thought reject the notion of punishment and deterrence; after all, if the requirement is perceived solely through the lens of morality, then there are no consequences or accountability for failure to act. The failure to adopt a mechanism whereby the bystander who fails to intervene is punished for doing so fails both the immediate victim and future victims.

The resistance from a majority of Utah legislators over the past two years requires us to address the following question: who is deserving of protection? If it is the victim, then the most obvious way to do so is to impose a legal requirement with criminal penalty; if it is the bystander, then failure to ratify State Rep. King's legislation ensures adoption of a bystander protection model. It is unclear why members of the Legislature would prefer protecting the able rather than extending protection to the vulnerable.

In the context of the "duty" question, the legislature has clearly laid down its marker: the "moral" bystander will "know what to do," and if that does not occur, then the victim will not be relieved of peril and there will be no consequences for walking away. Consequently, the Utah legislature has signaled that failing to provide assistance will be consequence free and the victim will be left to their own devices. In other words, legislators extend protection to the individual who fails to act on behalf of another member of society who needs assistance. This seems to be a sense of duty turned on its head: should not the primary focus of the Legislature be to extend protections to the weak, rather than the strong? After all, "in the moment," it is the victim who is weak and the bystander who is "strong."

In the debate before the House Judiciary Committee on January 21, 2018, one State Representative focused on the idea that this legislation was a "180-

${ }^{99}$ Duty to Assist in an Emergency: Hearing on H.B. 125, supra note 4; 911 Responsibilities in an Emergency: Hearing on H.B. 170, supra note 4. 
degree turn" from a legal standard that potentially has been in place "since the beginning of time," 100 and framed the issue in the following manner:

So, my question is, what is the compelling policy argument for changing a law that has essentially existed forever? You had suggested maybe so that we could mitigate the likelihood of crime or loss of life, but we're becoming a safer, less violent, nation all the time, it seems those arguments would fit more 100 years ago, or 200 years ago, or back in old England, in places and times when people were literally dying in the street and others walked by. We didn't do it then; we've resisted it until now. ${ }^{101}$

Another State Representative echoed similar concerns:

The challenge we have as legislators, as lawmakers, is do we take the moral imperative that most of us feel and now do we make it a legal imperative that has legal consequences? I'm not arguing with you about the fact that it is good, and it is the right thing, but we also try to be careful, and we recognize that words have meaning, and we also recognize as we sit here, that it's very difficult to anticipate all of the consequences as a result of passage. ${ }^{102}$

This same State Representative also voiced concern over the type and weight of the liability that such legislation may present: "I do believe it also does set a standard, because we're saying to the people of the state, 'if you fail to act in these situations, you're criminally liable.' Well clearly if I'm criminally liable I have a civil duty as well." 103

During the House floor debate on February 19, 2019, a third State Representative made a similar argument, delving into the second issue, which has been a significant source of concern for some legislators, and criminalizing the failure to act thereby legislating a "crime of omission":

Traditionally under criminal law, as the prior representative noted, the criminal law requires a criminal act, and criminal intent. Here we are criminalizing doing nothing, we are criminalizing inaction. Now references made to our current law where we have a duty to report abuse of children or abuse of the elderly, we make those exceptions in the law because of the distinct and unique vulnerability of children and elderly. This law, this bill rather, would open up that liability to society at large, to everyone, not just children and elderly but anyone who is in distress. And we impose a duty to report. That is a big leap, it is a

\footnotetext{
${ }^{100}$ Duty to Assist in an Emergency: Hearing on H.B. 125, supra note 4 (statement of Rep. Brian Greene, Member, H. Judiciary Comm.).

${ }^{101} I d$.

${ }^{102}$ Duty to Assist in an Emergency: Hearing on H.B. 125, supra note 4 (statement of Rep. Lowry Snow, Member, H. Judiciary Comm.).

${ }^{103} I d$.
} 
big leap for us to take in our law. ${ }^{104}$

The State Representative then referenced the murder of Sherrice Iverson and how it piqued his interest concerning Cash's liability under Utah law:

I did locate under Utah law, under existing law, section 76-2-202. It is our accomplice liability statute it says that anyone who "intentionally aids another person to engage in a crime can also be criminally liable for that crime." Intentionally aids, the case law in Utah, I read a few of the cases, how is that interpreted, aiding [sic] you're considered to aid in a crime, if you stand by and do nothing. And so, for example, in the case of State v. Cheney, a man was held liable under the accomplice liability statute for allowing his child to be raped. In the case of State v. Beltran-Felix, it was a case of a sexual assault where two men entered into a store, one of the men raped one of the women who was there while the other friend watched, or waited, allowing the crime to occur without intervention, and the observing friend was held liable for aiding his friend in the commission of a crime. ${ }^{105}$

While voicing his concern that criminalizing acts of omission would be a drastic departure from current legislature, the State Representative simultaneously made the argument that current Utah law does just that: "We have an existing law that allows those who do nothing in these situations where a crime is being occurred, where someone is in need, we allow them to be prosecuted as an accomplice." 106

After expressing that he appreciated the idea of sending a message that everyone should step up and be good Samaritans, one State Representative on the Floor Debate in February 2018 commented as follows:

I don't like the idea of legislating goodness. I think it's been mentioned before but the good people of Utah do reach out and I don't see that there's a problem. Maybe it'll require a few more, maybe we'll get a few more reports, but I worry more about the chilling effect that it might have. ${ }^{107}$

Along with other opponents to the bill, this State Representative was apprehensive about deviating from the status quo:

... it's just such a departure from our criminal code and our law, without any mens rea or action on your part, you can become a criminal by your inaction. While I recognize the need for vulnerable adults and our youth, I don't think we should take it to the extent that

\footnotetext{
104911 Responsibilities in an Emergency: Hearing on H.B. 170, supra note 4 (statement of Rep. Merrill Nelson).

${ }^{105} \mathrm{Id}$.

${ }^{106} I d$.

${ }^{107}$ Duty to Assist in an Emergency: Hearing on H.B. 125, supra note 4 (statement of Rep. Kelly Miles).
} 
this law does. ${ }^{108}$

What these four Representatives articulated-in the 2018 and 2019 Committee and Floor debates-highlights the principled reservations with the legislation. In a nutshell, the four State Representatives are expressing two separate but perhaps related concerns: imposing a legal duty to act on behalf of the bystander and penalizing the crime of omission. These issues - whether viewed separately or jointly — present the most compelling reason to vote against the legislation.

These concerns were oft-heard refrains when State Rep. King and the authors met with members of the Utah legislature; in some ways, it became a mantra for those opposing the proposed legislation. The question is what the source of this concern is and how best to overcome it.

Extending the "duty to act" necessarily focuses on the consequences of imposing a relationship between individuals where, otherwise, none exists. This is distinct from the relationship between an individual and the state in which the "duty" question is predicated on a contractual relationship. The discomfort expressed regarding the temporary-transient-fleeting relationship State Rep. King recommends focuses on the risks in creating an obligation between two individuals where one would not, otherwise, exist.

The Members of the Legislature prefer this duty be contained to a moralitymoral "boundary" rather than extension to the terrain of the law. That is, though recognizing that the person in distress would benefit from bystander intervention, criminalizing the failure or omission reflects government over-step in demanding particular actions. This argument is, frankly, bystander-focused rather than victim-centered.

That is the essence of the disagreement, highlighting distinct means of addressing the existential question of duty. By limiting it to an inquiry of moral values, framed in the traditional "we know to do the right thing," we are leaving an individual in peril to the good graces of another. In the inherently limited paradigm, should the bystander not intervene-limited to "dialing 911"- then there are three, if not four, results: no assistance to a victim, no punishment to the bystander for failing to provide assistance, and no deterrence to future bystanders, thereby arguably failing to provide assistance to future victims. From the perspective of present and future victims, this suggests a profound failure in their hour of need. It is, more than anything, abandonment compounded by a knowing, and deliberate, determination not to punish the bystander positioned to act.

While one assumes those legislators do not wish ill on the victim, the practical result of their opposition leads to that very result, whether intended or not. The hesitation to and recoil from legislating a crime of omission has the same consequence from the victim's perspective. More than that, criminal codes, including Utah's, include crimes of omission; two obvious examples are

${ }^{108} I d$. 
punishment for failing to stop at a stop sign and failure to pay taxes. In both situations, the legislature determined that the act of omission is punishable in a court of law.

Thus, the question is why these four State Representatives find creating a crime of omission so objectionable when the sole purpose of State Rep. King's legislation is to minimize harm to a vulnerable member of society. After all, that is the underlying basis for the proposal. Crimes of omission are intended to punish for a failure; is not walking away from a person in peril a failure? Therein appears the crux of the dilemma: what State Rep. King frames as a criminal failure, his peers perceive a moral failing. The division is profound; one suggests tolerating abandoning the victim, and the other would impose a criminal penalty.

These, then, are two distinct approaches to the age old saying, "am I my Brother's keeper": 109 who do we protect and what are the consequences of failing to create an accountability-predicated mechanism whereby minimal intervention is required, and omission is criminalized. The concerns articulated by the four State Representatives suggest that protection is to be extended to the bystander; the proposal introduced by State Rep. King proposes protecting the victim.

These are two distinct approaches to a critical societal question that intersects distinct disciplines. The morality-based approach extends protection to the non-intervening bystander; the legal based approach criminalizes that nonintervention. From the perspective of the victim - the person most in need of assistance - the failure to impose a requirement to intervene escalates the peril which, frankly, would seem to be the very antithesis of how the parable is intended to be answered.

\section{WHY IS BYSTANDER LEGISLATION A BAD IDEA?}

After listening to Utah legislators and cataloging other discussions of bystander legislation, the most frequent criticisms are summarized below.

\section{A. Prosecutorial Discretion}

Prosecutors are given a generous amount of discretion when it comes to deciding whether to prosecute. It has been well established that so long as a prosecutor does not base their decision to prosecute on an impermissible factor then there is no violation of due process. ${ }^{110}$

Although a prosecutor obviously cannot base charging decisions on a defendant's race, sex, religion, or exercise of a statutory or constitutional right, so long as the prosecutor has probable cause to believe that the accused committed an offense defined by statute, the decision whether or not to prosecute, and what charge to file . . .

${ }^{109}$ Genesis 4:9.

110 U.S. ConST. amend. XIV, § 2; Pugach v. Klein, 193 F. Supp. 630, 635 (S.D.N.Y. 1961); see also United States v. Andersen, 940 F.2d 593, 596 (10th Cir. 1991); United States v. Morehead, 959 F.2d 1489, 1499 (10th Cir. 1992). 
generally rests entirely in his discretion. ${ }^{111}$

When facing criminal charges, it justifiably makes a defendant uneasy that their case largely rests with an individual who can decide to bring charges based upon numerous factors. The system allows prosecutors to operate without judicial interference and narrows the review of a prosecutor's exercise of discretion in scope. ${ }^{112}$

Concern over prosecutorial misconduct has risen over the past few decades; however, this is not likely due to a rise in increasing prosecutorial misconduct and more likely the result of increasing media coverage of it. ${ }^{113}$ The increasing concern of prosecutorial misconduct has been met with a shift in regulations that are aimed towards great legal and political accountability for prosecutors. ${ }^{114}$

Prosecutors already must "consider three sets of reasons to decline or pursue charges: legal reasons, administrative reasons, and equitable reasons." 115 When gathering data from the ten states that have some form of bystander legislation, there was no evidence that crimes which arose under these statutes were being routinely prosecuted. This may be because factual findings to support that an individual willfully declined to assist an individual in crisis are difficult to establish.

The prosecutor's office likely thinks that a successful prosecutor is one who "works quickly, disposing of as many cases as possible through plea bargains." 116 The criminal penalty in most states for failure to assist only amounts to a misdemeanor, and, absent a clear path to conviction, it would appear that prosecutors are more inclined to quickly move on to more pressing matters. The Supreme Court of New Jersey has stated that prosecutors have a duty to examine each matter with "care and accuracy." 117 Prosecutors must keep in mind the relative importance to their community when determining which cases to prosecute, while also weighing the chances of success. ${ }^{118}$ It simply is not feasible for prosecutors to prosecute every matter brought before them. Failure to assist cases are unlikely to be prioritized by prosecutors unless they are confident they can establish every criminal element, which is difficult to do under such statutes, or if it is a matter of high importance to the community.

\footnotetext{
${ }^{111}$ United States v. Curtis, 344 F.3d 1057, 1064 (10th Cir. 2003) (citations omitted) (internal quotation marks omitted).

112 Royce A. Ferguson, JR., Criminal Practice \& Procedure $§ 3513$ (3d ed. 2019) (citing United States v. Smith, 354 A.2d 510, 513 (D.C. 1976)).

${ }^{113}$ Bruce Green \& Ellen Yaroshefsky, Prosecutorial Accountability 2.0, 92 NOTRE DAME L. REV. 51,87 (2016).

${ }^{114} \mathrm{Id}$. at 53 .

${ }^{115}$ Josh Bowers, Legal Guilt, Normative Innocence, and the Equitable Decision Not to Prosecute, 110 Colum. L. REV. 1655, 1655 (2010).

116 Janet C. Hoeffel, Prosecutorial Discretion at the Core: The Good Prosecutor Meets Brady, 109 PENN ST. L. REV. 1133, 1136 (2005).

${ }^{117}$ State v. Winne, 96 A.2d 63, 73 (N.J. 1953).

${ }^{118} \mathrm{Id}$.
} 


\section{B. Legislating Morality}

When attempting to pass bystander legislation through Utah's legislature, the notion that this is simply an attempt to legislate morality was commonly voiced by state representatives. ${ }^{119}$ This is not a new concern and has been stated many times in various ways:

It is, indeed, most highly desirable that [people] should not merely abstain from doing harm to their neighbors, but should render active services to their neighbors. In general however the penal law must content itself with keeping [individuals] from doing positive harm, and must leave to public opinion, and to the teachers of morality and religion, the office of furnishing [people] with motives for doing positive good. ${ }^{120}$

While some balk at the idea of legislating morality, it should not be forgotten that, for the first century following the establishment of the United States, courts consistently upheld moral legislation against constitutional challenges. ${ }^{121}$ Even in recent years, congressional legislation has been upheld by the U.S. Supreme Court primarily for the moral implications of the bill. ${ }^{122}$ When thinking of the origins of any legislation, it seems difficult to imagine that any were created without referencing some moral code. A precise definition of morality is difficult; however, in determining whether morality is a legitimate government interest, one scholar defined it as "a set of normative principles about: (1) how humans should properly conduct themselves; and (2) how humans should treat one another, whether acting singularly or in the aggregate." 123

Compare this to Black's Law Dictionary, which defines "law" as: "[t]he regime that orders human activities and relations through systematic application of the force of politically organized society, or through social pressure, backed by force, in such a society; the legal system."124

The overlap between morality and law is unmistakable. Law does have added pressures and is backed by force, but it seems a reasonable assumption that law is derived from moral considerations. If all proposed changes to legislation were met with the question - "isn't this just legislating morality?"it would greatly hamper a legislative process, which is already oft complained of as being too slow. This criticism should rightly be ignored so that the merits of the proposed legislative changes have time to be thoroughly discussed and

${ }^{119}$ Duty to Assist in an Emergency: Hearing on H.B. 125, supra note 4; 911 Responsibilities in an Emergency: Hearing on H.B. 170, supra note 4.

120 Thomas Babington Macaulay, A Penal Code Prepared by the Indian Law COMMISSIONERS 105 (1838).

${ }^{121}$ Daniel F. Piar, Morality as a Legitimate Government Interest, 117 PENN ST. L. REV. 139, 139 (2012).

${ }^{122}$ See Gonzales v. Carhart, 550 U.S. 124, 130 (2007) (upholding the Partial-Birth Abortion Ban Act of 2003, 18 U.S.C.A. $\S 1531$ (West 2003)).

${ }^{123}$ Piar, supra note 121 , at 141.

${ }^{124}$ Law, BLACK's LAW DiCTIONARY (11th ed. 2019). 
vetted before being approved or rejected.

\section{Creation of a "Nanny State"}

"Nanny state" is a pejorative term referring to "a government that overregulates its citizens by interfering with individual choice." 125 The term has been used to describe Michael Bloomberg's mayoral efforts to increase healthy standards of living through restricting the sale of large soft drinks along with regulating sodium and trans fats. ${ }^{126}$

While nanny state is typically used as a criticism, the term does not necessarily connote an adverse system. Regulations are meant to reduce the negative impact of "externalities," or more plainly: "if those imposing costs on others are forced to pay for these costs, society will get the socially optimal amount of the activity generating the costs." 127 The troublesome version appears where regulators create legislation that is meant to improve the life of an individual while disregarding any costs others may experience. ${ }^{128}$ This type of regulation has been described as "the interference . . . with another person, against their will, and justified by a claim that the person interfered with will be better off." 129

\section{Extra Burden on Emergency Service Personnel}

An inordinate burden on emergency services has been raised as a potential unintended side effect to bystander legislation. This may be an issue that cannot be addressed as a whole as each jurisdiction and municipality has different resources available to provide such public necessities.

During the process of attempting to pass bystander legislation in Utah, an active fire fighter and president of the Professional Fire Fighters of Utah-an organization comprised of firefighters throughout the state - testified in favor of the legislation. ${ }^{130} \mathrm{He}$ acknowledged that it would mean an increase in calls, but that firefighters are not afraid of work. ${ }^{131}$ Testifying as a firefighter who, from his estimations, goes on thousands of emergency calls a year, he stated that there were numerous times he had arrived at a scene only to wish that 911 had been called sooner. ${ }^{132}$

Each city, county, and state must look at the adequacy of their emergency systems. This should be done regardless of bystander legislation. Advancements in technology will only make responding to emergency calls more efficient and

125 Nanny State, BlacK's LaW DictionaRY (10th ed. 2014).

${ }^{126}$ Karen Harned, The Michael Bloomberg Nanny State in New York: A Cautionary Tale, ForBES (May 10, 2013, 8:00 AM), https://www.forbes.com/sites/realspin/2013/05/10/the-michael-bloom berg-nanny-state-in-new-york-a-cautionary-tale/\#4cc7c5f07109 [https://perma.cc/Q28K-UUFC].

${ }^{127}$ M. Todd Henderson, The Nanny Corporation, 76 U. CHI. L. REV. 1517, 1522-23 (2009).

${ }^{128} \mathrm{Id}$.

${ }^{129} \mathrm{Id}$.

${ }^{130}$ Duty to Assist in an Emergency: Hearing on H.B. 125, supra note 4 (statement of Jack Tidrow).

${ }^{131} \mathrm{Id}$.

${ }^{132} \mathrm{Id}$. 
ease the burdens that individuals who deal with emergency situations face every day.

The best way to determine the potential effects that bystander legislation may have on emergency service personnel would be to ascertain whether there was a negative impact on the ten states previously mentioned after they enacted such legislation. Differing forms of bystander legislation have been passed since 1967 , and there has been no data to suggest that those who provide emergency services have experienced any adverse impacts.

\section{E. Creates the Possibility of Extra Criminal Liability}

Many criminal statutes consider as a general rule that "a person is guilty of involuntary manslaughter when as a direct result of the doing of an unlawful act in a reckless or grossly negligent manner, or the doing of a lawful act in a reckless or grossly negligent manner, he causes the death of another person." 133

If there is a legally required duty to assist, then it could become an "unlawful act" not to assist. Further, if someone were to die due to a person's inaction, that person could be guilty of involuntary manslaughter.

Those already hesitant about creating criminal liability for inaction become much more prone to objection at the idea that such a law could be used as a basis for heightening criminal liability. Concern over heightened criminal liability has not gone unnoticed by legislators. In 2019, State Rep. King introduced duty to assist legislation that addressed this concern. The language in State Rep. King's proposed bill was as follows: "[n]otwithstanding any contrary provision of state law, a prosecutor may not use an individual's violation of Subsection (2) as the basis for charging the individual with another offense."134

This language unequivocally abolishes any fear that an individual will be charged with a secondary crime based upon their violation of State Rep. King's proposed duty to assist bill.

\section{F. Creates the Possibility of Civil Liability}

Some are concerned that the civil liability attached to bystander legislation is too great to justify any potential benefits. Legislators can easily dispel this concern by including a provision that reads something akin to the following: "nothing contained in this section shall alter existing law with respect to civil liability." Whether the concerns are so great that legislators feel the need to include such a provision is a discretionary decision.

Absent a provision exculpating an individual from civil liability, there are still barriers towards bringing a civil action based upon bystander legislation. In Wisconsin, a case was tried where the parents of a sixteen-year-old, whose life was tragically cut short, attempted to bring a wrongful death suit with its basis in the state's bystander legislation. ${ }^{135}$ The complaint alleged the defendant's

${ }^{133}$ E.g., 18 PA. STAT. AND CONS. STAT. ANN. § 2504(a) (West 1995).

${ }^{134}$ H.B. 170, 2019 Leg., 63d Sess. (Utah 2019).

${ }^{135}$ Logarta v. Gustafson, 998 F. Supp. 998, 1000 (E.D. Wis. 1998). 
inaction negligently led to their son's death. ${ }^{136}$ The claim was dismissed because the plaintiffs were unable to establish that the defendant's inactions were the proximate cause of their son's death. ${ }^{137}$

Bringing a civil suit based upon bystander legislation requires the plaintiff to show that, if the defendant had acted, then the injury or alleged damages would not have occurred or would have been lessened. Bystander legislation applies to individuals that had nothing to do with an individual's original source of peril. The obligation to assist or call for help only is triggered once an individual is already suffering a serious physical injury that the bystander did not contribute to in any way. Proving in civil litigation that "but for" the bystander's inactions the injury could not have taken place or was causally aggravated by those inactions is a difficult burden to meet. Every civil suit listed on Lexis or Westlaw that is predicated upon bystander legislation failed because of the inability to establish that the bystander proximately caused or aggravated any damages. ${ }^{138}$

Civil suits based on duty to assist legislation have proven difficult for their proponents; however, the possibility of them being brought at all remains a concern for some. State Rep. King attempted to allay all fears of civil liability with language in his proposed bill:

This section does not create an independent basis for civil liability for failure to provide the assistance described in this section. The fact that an individual is charged with a crime under this section may not be used to establish that the individual violated a duty on which a claim for personal injuries may be based. ${ }^{139}$

\section{G. Distrust of Law Enforcement}

Research suggests that fear of police involvement is among the top reasons that individuals do not call or delay calling for help in an emergency. ${ }^{140}$ This is particularly common in situations that involve drug overdoses. ${ }^{141}$ In an attempt to encourage individuals to call 911 , forty states (as of July 25,2017 ) have passed laws that provide protection from prosecution for certain drug offenses for both the person calling for medical assistance and the person who has overdosed. ${ }^{142}$

Fear of law enforcement is also very real in minority communities. According to the American Psychological Association (APA), "the probability

\footnotetext{
${ }^{136} I d$.

${ }^{137} \mathrm{Id}$. at 1007 .

${ }^{138}$ See, e.g., Logarta v. Gustafson, 998 F. Supp. 998 (E.D. Wis. 1998); Lewis v. Bellows Falls Congregation of Jehovah's Witnesses, No. 1:14-CV-205, 2015 WL 13501874, at *5 (D. Vt. July 16, 2015); Estate of Cilley v. Lane, 985 A.2d 481, 486 (Me. 2009).

${ }^{139}$ H.B. 104, 2020 Leg., 63d Sess. (Utah 2020) (internal subdivisions omitted).

${ }^{140}$ Melissa Tracy et al., Circumstances of Witnessed Drug Overdose in New York City: Implications for Intervention, 79 DRUG \& AlCOHOL DEPENDENCE 181, 183-84 (2005).

${ }^{141} I d$.

${ }^{142}$ Good Samaritan Fatal Overdose Prevention Laws, DRUG POL'y Alliance, http://www.drugp olicy.org/issues/good-samaritan-fatal-overdose-prevention-laws [https://perma.cc/4LDV-AEM2].
} 
of being black, unarmed and shot by police is about 3.5 times the probability of being white, unarmed and shot by police." 143 The APA states that "[r]educing and circumventing bias is one way to chip away at the disparities in how police treat black civilians." 144 There are many ways to approach racially disparate treatment by law enforcement, but it is a systematic problem that will take years, if not decades, to solve. There is no evidence to suggest that the passage of duty to assist legislation will have a positive or negative effect on the issues that minorities face when it comes to law enforcement.

Human Rights Watch, an international, non-governmental organization, stated that public safety is undermined because immigrant communities in the United States are afraid of calling law enforcement. ${ }^{145}$ Crimes, like rape, go unreported because victims fear that calling law enforcement will result in their deportation. ${ }^{146}$ Individuals at the Human Rights Watch suggest that this problem is difficult to fix on a community or state level and the best way to combat this problem is for the U.S. Congress to pass comprehensive immigration reform. ${ }^{147}$

There are also those with family members who are mentally ill that resist calling law enforcement out of fear that it may turn into a deadly encounter. ${ }^{148}$ In 2017, a mother in Brooklyn called 911 when her thirty-two-year-old son with schizophrenia was acting erratically. ${ }^{149}$ Police were unable to calm the man and opened fire after he lunged at them with a knife. ${ }^{150}$ Calling 911 to report emotionally disturbed individuals has often resulted in the problem escalating. ${ }^{151}$ Efforts in New York City, and other cities alike, have been made so that officers receive crisis intervention training and have attempted to deploy more teams to calls involving the mentally ill that consist of a cop and a social worker. ${ }^{152}$

While there may be those who have a justified fear of calling 911, this should not bar the implementation of duty to assist legislation. State Rep. King's proposed bill, along with other duty to assist bills already in place, does not require an individual to remain at the scene after calling 911.

\section{H. Aiding and Abetting Laws}

States have differing versions of aiding and abetting laws, but the purpose of these statutes is to hold an individual liable for another's actions. Assisting another individual to commit a criminal act is in itself criminal and makes the

${ }^{143}$ Kirsten Weir, Policing in Black \& White, 47 AM. PSYCHOL. Ass’N 36 (Dec. 2016).

${ }^{144} I d$.

${ }^{145}$ US: Immigrants 'Afraid to Call 911', HuM. RTS. WATCH (May 14, 2014, 11:55 PM), https://ww w.hrw.org/news/2014/05/14/us-immigrants-afraid-call-911 [https://perma.cc/2L6K-U4PR].

${ }^{146} I d$.

${ }^{147} I d$.

${ }^{148}$ Rich Schapiro, Families of Mentally Ill Fear Calling Police May Turn into Deadly Encounter, N.Y. DAILY NEwS (Apr. 05, 2018, 11:01 PM), https://www.nydailynews.com/new-york/familiesmentally-ill-fear-calling-police-turn-deadly-article-1.3917552 [https://perma.cc/R7F8-6P3P].

${ }^{149} I d$.

${ }^{150} \mathrm{Id}$.

${ }^{151} I d$.

${ }^{152} I d$. 
assistor an accomplice to that act. Accomplice liability is a basic principle of criminal law which can be misinterpreted and is easier to understand when broken down into its separate elements:

Proof of aider and abettor liability requires proof in three distinct areas: (1) the direct perpetrator's actus reus, or a crime committed by direct perpetrator; (2) the aider and abettor's mens rea, or knowledge of direct perpetrator's unlawful intent and intent to assist in achieving those unlawful ends; and (3) the aider and abettor's actus reus, or conduct by the aider and abettor that in fact assists achievement of crime. ${ }^{153}$

Utah's law concerning criminal responsibility for direct commission of offense or for conduct of another reads as the following: "[e]very person, acting with the mental state required for the commission of an offense who directly commits the offense, who solicits, requests, commands, encourages, or intentionally aids another person to engage in conduct which constitutes an offense shall be criminally liable as a party for such conduct." 154

This language has been misconstrued by some who believe it should be interpreted as holding individuals accountable for acts and situations that bystander legislation is said to cover. ${ }^{155}$ Under this current legislation there would be no liability for David Cash, who consciously decided not to report the rape and murder of seven-year-old Sherrice Iverson. The District Attorney in that case explained that to charge Cash with aiding and abetting, "we would have to have evidence that Cash actually did something ... with the thought and intent of helping Strohmeyer." 156

Aiding and abetting statutes do not hold individuals responsible for choosing to do nothing after witnessing a crime or seeing someone in distress. According to the U.S. Supreme Court, "[i]n order to aid and abet another to commit a crime it is necessary that a defendant 'in some sort associate himself with the venture, that he participate in it as in something that he wishes to bring about, that he seek by his action to make it succeed."'157

Bystander legislation bridges the gap between instances where individuals act in concert together to commit a crime and those where an individual simply chooses not to summon assistance for someone they know is suffering a serious bodily injury. It is the difference between active criminal intent and callous indifference for the life of another human being.

15317 CAL. JUR. 3D CRIMINAL LAW: CORE ASPECTS $§ 148$ (2019).

${ }^{154}$ UTAH CODE ANN. § 76-2-202 (West 1973).

${ }^{155}$ Duty to Assist in an Emergency: Hearing on H.B. 125, supra note 4; 911 Responsibilities in an Emergency: Hearing on H.B. 170, supra note 4.

156 Slaying Suspect's Friend Not Seen as Accomplice, L.A. TIMES (June 3, 1997, 12:00 AM), https://www.latimes.com/archives/la-xpm-1997-06-03-mn-65196-story.html [https://perma.cc/K7 GD-7RWP].

${ }^{157}$ Nye \& Nissen v. United States, 336 U.S. 613, 619 (1949) (citing United States v. Peoni, 100 F.2d 401, 402 (2d Cir. 1938) (written by Hand, J.)). 


\section{GOING FORWARD}

The issue we have addressed in this article is amongst the most important confronting an increasingly divisive, divided, and distant culture. The notion of compromise, reconciliation, and efforts to understand the "other" are archaic. In this atmosphere, the notion of "doing the right thing" is quainter than ever. That aspirational moral code is just that, an aspirational model code. Perhaps in a different era, not marked by the tone and tenor of today's interaction, such an ideal might have "held water."

It harkens, seemingly, to a simpler day, recalling a 1950's "father knows best" environment. While the nostalgia is admirable, if not understandable, it is of no benefit to the victim in need of assistance. That, ultimately, is the reason we propose imposing a legal obligation on the bystander.

The proposed obligation on the bystander is minimal: just dial 911. The obligation is imposed only when the victim has knowledge of bystander peril and has the capability to act; furthermore, the burden is mitigated if acting endangers the bystander. From a cost-benefit perspective, the burden on the bystander is minimal whereas the benefit to the victim is significant. While we are sensitive to the arguments opposing the proposal, particularly the notion of "legislating morality," we are of the belief that the discomfort, however valid, fails to recognize the primacy of the victim's needs.

The notion that imposing a legal duty on the bystander to dial 911 is akin to "legislating morality" reflects two distinct approaches to the core question of "to whom-what is a duty owed." In recommending the imposition of criminal penalty on the bystander, we are of the opinion that a duty to fully reflect society's recognition that a victim in peril requires assistance must be codified in the criminal code.

Otherwise, it is not a duty but rather an amorphous concept, lacking weight and substance. If not codified in the criminal code, there is no penalty for failing to provide minimal assistance to the victim, thereby freeing the bystander of any consequence or accountability. From the victim's perspective, that is akin to abandonment in the greatest hour of need. As history repeatedly demonstrates, "consequence free" abandonment is the norm when examining the "interaction" between victim and bystander.

It is that recurring pattern that our proposal seeks to tackle. While the proposed penalty (in Utah) is modest - a Class B Misdemeanor with a penalty of $\$ 1,000$ and/or six months incarceration-imposing a legal duty is, from the victim's perspective, most significant. It is not an exaggeration to suggest it may well be the difference between life and death. At the very least, it is the difference between assistance in a time of peril and abandonment in a time of peril. This is not a matter of "legislating morality," but rather of imposing an important legal duty on a person capable of assisting a person in peril.

However, a criminal code in and of itself is insufficient; undertaking a significant educational effort is essential. Such an effort must be broad in scope and ambitious in its goals. Devoid of such a determined focus, the legislation will not carry its intended weight and will not have the desired impact. Re-stated, 
bystander legislation, to have the greatest impact, must be inculcated and embedded into the core of society in a systematic and institutionalized manner. This, then, is a "two-front" undertaking: law and education.

Our focus on the law and education is distinct from the voices of opposition who rely on morality and basic human goodness. Because the argument is compelling, it understandably resonates in many quarters. However, the argument falls short when considered from the victim's, rather than the bystander's, perspective. Framing the argument in this context-victim or bystander - clarifies the dilemma confronting society, both practically and existentially: to whom is a duty owed. That, more than anything, defines the question of bystander obligation.

In framing the query as legal — not moral — the path we recommend moving forward is clear. The most appropriate manner to ensure consequences for failing to provide assistance to the person in peril is imposition of criminal penalty. To rely on the "hopeful" - for that is the essence of a moral based approach-is to fail the victim in the most critical hour of need. As both the pages of history and contemporary accounts unequivocally demonstrate, victim reliance on the "rightness-goodness" of the bystander is a misbegotten fallacy. Reversing course, and on behalf of future victims, adopting a twin-track approach of legislation and education is the most effective mechanism for providing assistance to a human being in peril.

Final Thought: That is the most correct and effective answer to the question: to whom is a duty owed. 


\section{APPENDIX $^{158}$}

Proposed Legislation: Representative King's legislation has been edited and tailored to bestow a legal duty upon individuals in the most limited of circumstances. The bill, as introduced during the 2019 legislative session, and as likely will be introduced in upcoming sessions if, and until, it is passed, reads as the following:

Representative Brian S. King proposes the following substitute bill:

\section{RESPONSIBILITIES IN AN EMERGENCY 2019 GENERAL SESSION \\ STATE OF UTAH}

Chief Sponsor: Brian S. King

Senate Sponsor:

LONG TITLE

General Description:

This bill relates to the duty to contact emergency services in an emergency.

Highlighted Provisions:

This bill:

- defines terms;

- makes it a class B misdemeanor to fail to contact emergency services in the event of a crime or another emergency subject to certain exceptions;

- prohibits a prosecutor from basing charges for commission of an offense other than the offense created in this bill on an individual's failure to contact emergency services;

- amends provisions of the Good Samaritan Act to provide immunity from liability to an individual who contacts emergency services in accordance with the requirements of this bill;

- addresses civil liability issues related to this bill; and

- makes technical changes.

Money Appropriated in this Bill: None

Other Special Clauses: None

Utah Code Sections Affected:

AMENDS:

78B-4-501, as last amended by Laws of Utah 2018, Chapter 62

\footnotetext{
${ }^{158}$ UtAH CODE ANN. § 76-9-1101 (West 1953).
} 


\section{ENACTS:}

76-9-1101, Utah Code Annotated 1953

Be it enacted by the Legislature of the state of Utah:

Section 1. Section 76-9-1101 is enacted to read:

\section{Part 11. Failure to Provide Assistance}

\section{6-9-1101. Failure to provide assistance.}

(1) As used in this section:

(a) (i) "Assistance" means making reasonable effort to contact paramedics, fire protection, law enforcement, or other appropriate emergency services.

(ii) "Assistance" does not include action that places the individual taking the action, or another individual, in danger.

(b) "Emergency" means that an individual is suffering from serious bodily injury and is in need of assistance.

(c) "Legal privilege" means any privilege designated by common law, statute, or rule of evidence.

(d) "Serious bodily injury" means injury that involves a substantial risk of death, unconsciousness, extreme physical pain, protracted and obvious disfigurement, or protracted loss or impairment of the function of a bodily member, organ, or mental faculty.

(2) An individual is guilty of a class B misdemeanor if the individual:

(a) observes that a crime has occurred or is occurring or that an emergency is occurring;

(b) has personal knowledge that another individual is suffering serious bodily injury resulting from a crime or emergency;

(c) is able to provide reasonable assistance to the individual described in Subsection (2)(b); and

(d) fails to provide reasonable assistance to the individual described in Subsection (2)(b).

(3) An individual is not guilty of violating Subsection (2) if the individual reasonably believes another individual has, or likely has, already provided or is providing reasonable assistance to the individual described in Subsection (2)(b).

(4) Notwithstanding any contrary provision of state law, a prosecutor may not use an individual's violation of Subsection (2) as the basis for charging the individual with another offense.

(5) This section does not create an independent basis for civil liability for failure to provide the assistance described in this section.

(6) The fact that an individual is charged $\hat{\mathrm{H}} \rightarrow$ or convicted $\leftarrow \hat{\mathrm{H}}$ with a crime under this section may not be used to establish that the 
individual violated a duty on which a claim for personal injuries may be based.

(7) Subsection (2) does not apply to the extent that an individual is prohibited from providing assistance by a legal privilege.

Section 2. Section 78B-4-501 is amended to read:

\section{B-4-501. Good Samaritan Law.}

(1) As used in this section:

(a) "Child" means an individual of such an age that a reasonable person would perceive the individual as unable to open the door of a locked motor vehicle, but in any case younger than 18 years of age.

(b) "Emergency" means an unexpected occurrence involving injury, threat of injury, or illness to a person or the public, including motor vehicle accidents, disasters, actual or threatened discharges, removal or disposal of hazardous materials, and other accidents or events of a similar nature.

(c) "Emergency care" includes actual assistance or advice offered to avoid, mitigate, or attempt to mitigate the effects of an emergency.

(d) "First responder" means a state or local:

(i) law enforcement officer, as defined in Section 53-13-103;

(ii) firefighter, as defined in Section 34A-3-113; or

(iii) emergency medical service provider, as defined in Section 26-8a-102.

(e) "Motor vehicle" means the same as that term is defined in Section 41-1a-102.

(2) A person who renders emergency care at or near the scene of, or during, an emergency, gratuitously and in good faith, or as required under Section 76-9-1101, is not liable for any civil damages or penalties as a result of any act or omission by the person rendering the emergency care, unless the person is grossly negligent or caused the emergency.

(3) (a) A person who gratuitously, and in good faith, assists a governmental agency or political subdivision in an activity described in Subsections (3)(a)(i) through (iii) is not liable for any civil damages or penalties as a result of any act or omission, unless the person rendering assistance is grossly negligent in:

(i) implementing measures to control the causes of epidemic and communicable diseases and other conditions significantly affecting the public health, or necessary to protect the public health as set out in Title 26A, Chapter 1, Local Health Departments;

(ii) investigating and controlling suspected bioterrorism and disease as set out in Title 26, Chapter 23b, Detection of Public Health Emergencies Act; and

(iii) responding to a national, state, or local emergency, a public health emergency as defined in Section 26-23b-102, or a declaration 
by the president of the United States or other federal official requesting public health-related activities.

[(3)](b) The immunity in this Subsection (3) is in addition to any immunity or protection in state or federal law that may apply.

(4) (a) A person who uses reasonable force to enter a locked and unattended motor vehicle to remove a confined child is not liable for damages in a civil action if all of the following apply:

(i) the person has a good faith belief that the confined child is in imminent danger of suffering physical injury or death unless the confined child is removed from the motor vehicle;

(ii) the person determines that the motor vehicle is locked and there is no reasonable manner in which the person can remove the confined child from the motor vehicle;

(iii) before entering the motor vehicle, the person notifies a first responder of the confined child;

(iv) the person does not use more force than is necessary under the circumstances to enter the motor vehicle and remove the confined child from the vehicle; and

(v) the person remains with the child until a first responder arrives at the motor vehicle.

[(4)](b) A person is not immune from civil liability under this Subsection (4) if the person fails to abide by any of the provisions of Subsection (4)(a) or commits any unnecessary or malicious damage to the motor vehicle. 